\title{
Perbandingan Susu Sapi Perah pada Pemerahan Pagi dan Sore Terhadap Total Plate Count dan Colioform di KUD Gemah Ripah, Sukabumi Jawa Barat
}

\author{
Raden Febrianto Christi*, Didin Supriat Tasripin, Dwi Suharwanto, Eka Wulandari
}

\author{
Fakultas Peternakan Universitas Padjadjaran \\ Jalan Raya Bandung-Sumedang Km 21, Sumedang Telp (022) 7798241 Fax (022)7798212 \\ *Email korespondensi: raden.febrianto@unpad.ac.id
}

(Diterima 15-10-2019; disetujui 30-12-2019)

\begin{abstract}
ABSTRAK
Susu adalah cairan putih yang keluar dari ambing sapi perah yang memiliki kandungan gizi yang baik. Kualitas susu sangat dipengaruhi oleh beberapa faktor salah satunya adalah total plate count (TPC) dan colioform. Tujuan penelitian ini adalah untuk mengetahui perbandingan susu sapi perah pada pemerahan pagi dan sore terhadap TPC dan colioform di KUD Gemah ripah, Sukabumi. Metode penelitian yang digunakan adalah uji t berpasangan dengan sampel ternak sapi perah 14 ekor yang masing-masing diulang sebanyak 7 ekor dengan masa laktasi sama. Sampel susu diambil 100ml dari setiap ekor dengan waktu pemerahan berbeda kemudian dimasukkan pada coolbox untuk dilakukan pengujian nilai TPC dan colioform di laboratoium. Hasil penelitian menunjukkan bahwa TPC dan colioform pada pemerahan susu pagi hari menghasilkan pengaruh nyata $(\mathrm{P}<0,05)$ dibandingkan pada susu hasil pemerahan sore yaitu $1,1 \times 10^{6} \mathrm{CFU} / \mathrm{ml}$ dan $6985,714 \mathrm{CFU} / \mathrm{mL}$. Kesimpulan menunjukkan bahwa terdapat perbedaan antara kualitas mikrobiologis yaitu TPC dan colioform antara susu pada pemerahan pagi dan sore serta dalam kategori normal sesuai standar dengan SNI 3141.1-2011.
\end{abstract}

Kata kunci : colioform, pemerahan pagi sore, susu sapi perah, total plate count,

\section{ABSTRACK}

Milk is a white liquid that comes out of a dairy cow's udder which has good nutritional content. Milk quality is strongly influenced by several factors, one of which is the Total Plate Count and Coloform. The purpose of this study was to determine the comparison of milk from dairy cows in the morning and evening milking of TPC and Colioform in KUD Gemah Ripah, Sukabumi. The research method used was paired $t$ test with samples of 14 dairy cows, each of which was repeated as many as 7 with the same lactation period. Milk samples were taken $100 \mathrm{ml}$ from each tail with different milking times and then put in a coolbox for testing the value of TPC and Coloform in Laboratory. The results showed that TPC and colioform in milking in the morning produced a significant effect $(\mathrm{P}<0.05)$ compared to milk produced by afternoon milking namely 1.1 x $106 \mathrm{CFU} / \mathrm{ml}$ and $6985.714 \mathrm{CFU} / \mathrm{mL}$. The conclusion shows that there is a difference between the microbiological quality of TPC and colioform between milk in morning and afternoon milking and in the normal category according to SNI 3141.1-2011.

Keywords: colioform, dairy cow milk, milking morning afternoon, total plate count

\section{PENDAHULUAN}

Kebutuhan susu Nasional tidak mampu memenuhi kebutuhan masyarakat Indonesia hal ini karena banyak sekali faktor yang mempengaruhi kuantitas dan kualitas produk susu yang dihasilkan. Jumlah Produksi susu setiap tahunnya selalu mengalami fluktuatif. Konsumsi susu masyarakat
Indonesia rata-rata adalah 1,8 g/kapita/hari, angka tersebut jauh lebih rendah jika dibandingkan dengan angka konsumsi yang ada. Data membuktikan bahwa produksi susu yang dihasilkan dalam negeri hanya sekitar 1,4 juta liter/hari, sedangkan sisanya harus melakukan proses importasi dari luar untuk memenuhi standar nasional. 
Sukabumi merupakan salah satu wilayah atau daerah di Jawa Barat sebagai sentra penghasil susu sapi perah Kecamatan Sukalarang Kabupaten Sukabumi merupakan wilayah dengan jumlah produksi susu penghasil terbanyak dibandingkan dengan Kecamatan yang lain. Tahun 2018. Populasi sapi perah di Sukabumi mencapai 776 ekor dengan total produksi sebesar 3627 liter dengan produk susu cukup tinggi tetapi kebersihan lingkungan belum menjadi suatu kesadaran bagi masyarakat sehingga dapat menyebabkan adanya kontaminasi mikroorganisme yang akan mempengaruhi terhadap kualitas susu.

Susu merupakan cairan putih yang keluar dari ambing sapi perah dengan keadaan segar serta memiliki kandungan gizi tinggi karena mengandung zat makanan yang lengkap dan seimbang seperti protein, lemak, karbohidrat, mineral, dan vitamin yang dibutuhkan oleh manusia. Status gizi yang tinggi pada susu menyebabkan mudahnya mikroorganisme untuk tumbuh kembang, sehingga dalam kurun waktu yang singkat susu tidak layak minum bahkan jika dipasarkan akan mengalami proses penolakan (Zain, 2013).

Umumnya pemerahan susu di tingkat peternak rakyat dilakukan sebanyak dua kali yaitu pemerahan di pagi dan sore hari. Selama proses pemerahan terkadang lupa terhadap tahapan atau prosedur karena biasanya peternak dalam melakukan kegiatan ini ingin dilaksanakan secara cepat,bahkan menghemat tenaga yang dikeluarkan. Kualitas susu pada pagi dan sore hari rata-rata memiliki perbedaan baik dari jumlah produksi maupun kualitas susu yang dihasilkan. Penanganan susu yang salah menyebabkan daya simpan susu menjadi tidak tahan lama, harga jual yang murah dapat menurunkan pendapatan peternak sebagai produsen susu.

Kerusakan yang terjadi dalam susu yang diakibatkan oleh peran aktif dari mikroorganisme jenis bakteri yang memanfaatkan kompenen gizi susu sehingga menurunkan kualitas susu yang ditandai oleh perubahan rasa menjadi pahit, aroma tidak khas susu, warna putih kehijauan. Kondisi yang demikian faktanya susu segar perlu mendapatkan penanganan yang benar agar kualitasnya tetap terjaga, antara lain lama waktu dan suhu penyimpanan susu. Pada dasarnya indicator yang dijadikan susu baik atau tidaknya adalah Jumlah bakteri dalam susu (total plate count) dan colioform. Berdasarkan uraian permasalahan yang terjadi, maka tidak hanya cukup pemeriksaan secara fisik terhadap susu tetapi mikrobiologis pada susu sapi segar perlu dilakukan pula. Hal tersebut dapat dijadikan bahan pertimbangan agar terdapat adanya jaminan konsumen dalam menerima susu yang kualitas tinggi dan memberikan peluang masyarakat agar peternakan sapi perah semakin berkembang (Hidayat, 2010). Tujuan penelitian adalah untuk membandingkan kandungan Total Plate Count dan Koiloform susu di Peternak Sapi Perah Binaan KUD Gemah Ripah Sukabumi Jawa Barat dengan Standar Nasional Indonesia.

\section{MATERI DAN METODE}

\section{Materi}

Alat yang digunakan dalam penelitian antara lain tabung reaksi, cawan petri, botol media, pipet volumetric, penghitung koloni (colony counter), gunting, pinset, jarum inokulasi, timbangan, magnetic stirer, bunsen, pengocok tabung (vortex), inkubator, penangas air, lemari steril, lemari pendingin, autoklaf, dan freezer. Bahan meliputi: PCA, buffer peptone, $0,1 \%$ spirtus, sampel susu.

\section{Metode}

Sampel susu sebanyak 14 yang diambil dari 3 kelompok peternak. Sampel susu diambil 2 kali yaitu pemerahan pagi dan pemerahan sore. Masingmasing sampel sebanyak $100 \mathrm{ml}$ dimasukkan dalam botol steril dan dalam cooling box yang berisi es. Pengambilan sampel dilakukan tiap satu minggu sekali pada pagi hari dengan rentang waktu sekitar pukul 06.00 WIB sampai dengan pukul 09.00 WIB. Dilaboratorium sampel dilakukan proses tahapan pengenceran mulai ke 1-6 (tahapan prosedur). Selanjutnya masing-masing diambil $1 \mathrm{ml}$ dan dimasukkan ke cawan petri. Kemudian, 15 ml PCA cair diamkan dalam penangas $55^{\circ} \mathrm{C}$ ditambahkan ke dalam cawan petri.

Metode pengukuran TPC dan coiloform mengacu berdasarkan penelitian Putri \& Kurnia (2018) yaitu cawan diputar ke depan dan ke belakang (dengan cara manual) atau membentuk angka delapan agar larutan contoh dan media PCA tercampur sempurna dan didiamkan sampai larutan tersebut menjadi padat. Cawan petri diletakkan dengan posisi terbalik dan diinkubasi pada suhu $37^{\circ} \mathrm{C}$ selama $24 \mathrm{jam}$. Total plate count (TPC) dilaporkan sebagai cawan spreader bila cawan banyak ditumbuhi oleh rantai koloni tidak terpisah secara jelas dengan total area yang melebihi $75 \%$. Rata-rata banyaknya koloni dari setiap pengenceran, dilaporkan jumlahnya sebagai TPC. Sedangkan pengujian coliform menggunakan metode MPN (most probable number) dengan 3 seri tabung dengan mencocokan kombinasi hasil tabung positif dengan tabel MPN, pengujian terdiri dari uji 
pendugaan (presumptive test), uji penegasan (confirmed test) dan uji pelengkap (complited test).

\section{Variabel}

Variabel yang diamati dalam penelitian ini adalah Total Plate Count dan Colioform dengan rumus perhitungan:

Keterangan:

$$
\mathrm{N}=\frac{\text { Jumlah koloni per cawan }}{\text { Faktor Pengenceran }}
$$

$\mathrm{N}=$ jumlah koloni produk (per ml atau per gram); Faktor pengenceran $=$ pengenceran $\mathrm{x}$ jumlah yang ditumbuhkan; Catatan, bila jumlah koloni per cawan lebih besar dari 250 pada seluruh pengenceran, maka melaporkan hasilnya sebagai terlalu banyak dihitung (TBUD).

\section{Analisis Statistik}

Perolehan data dianalisis dengan uji perbandingan rata-rata, yaitu: $x=$ Pemerahan Pagi, $\mathrm{y}=$ Pemerahan Sore. Masing-masing diulang sebanyak 14 kali, data diuji dengan menggunakan uji t berpasangan (Sudjana, 2005).

\section{Hipotesis :}

$\mathrm{H}_{0}: \mathrm{x}=\mathrm{y}$, berarti menghasilkan total TPC dan coiloform yang sama.

$\mathrm{H}_{1}: \mathrm{x} \neq \mathrm{y}$, ada perbedaan dari kedua pemerahan.

\section{Kaidah keputusan:}

Jika $\mathrm{t}_{\text {hitung }} \leq \mathrm{t}_{\text {tabel }}$ maka $\mathrm{H}_{0}$ diterima dan $\mathrm{H}_{1}$ ditolak, serta jika $\mathrm{t}$ hitung $>\mathrm{t}$ tabel maka $\mathrm{H}_{0}$ ditolak dan $\mathrm{H}_{1}$ diterima.

\section{HASIL DAN PEMBAHASAN}

Susu merupakan salah satu bahan dengan bentuk cair yang dihasilkan oleh ternak sapi perah dan dapat bermanfaat bagi masyarakat sebagai penyedia protein hewani dengan berbagai macam nutrient dan sumber kalsium bagi tubuh (Meutia et al., 2016). Berdasarkan Tabel 1 bahwa di dapat rataan TPC $(\mathrm{cfu} / \mathrm{ml})$ pada pemerahan pagi dan sore yaitu $1,1 \times 10^{6} \mathrm{cfu} / \mathrm{ml}$ serta $1 \times 10^{6} \mathrm{cfu} / \mathrm{ml}$. Sedangkan Colioform dihasilkan 6,985 x $10^{3}$ dan $6,082 \times 10^{3}$. Nilai hasil penelitian tersebut apabila dibandingkan dengan kualitas SNI 2011 masih jauh dari apa yang diharapkan karena untuk standar yang baik jumlah bakteri tidak boleh lebih dari $1 \times 10^{6} \mathrm{cfu} / \mathrm{ml}$. Hasil uji t menunjukaan bahwa pemerahan pagi hari lebih banyak jumlah TPC dibandingkan dengan pemerahan sore hari $(\mathrm{P}<0,05)$. Begitu juga dengan nilai colioform pada pemerahan pagi hari menyebabkan jumlah atau totalnya lebih besar dibandingkan pada pemerahan sore hari. Menurut Meutia et al. (2016), susu sapi segar asal peternak menunjukkan total bakteri sangat tinggi dan beberapa kesalahan dalam sanitasi produksi, hygiene buruk dan suhu penyimpanan. Zain (2013) menyatakan bahwa bakteri dalam susu segar dapat berasal dari ternak yang mengalami penyakit mastitis subklinis atau klinis, lingkungan kandang terutama sumber air dan peralatan yang digunakan untuk menyimpan susu serta selama pendistribusian. Resiko susu terkontaminasi oleh bakteri patogenik akan lebih

Tabel 1. Perbandingan nilai total plate count dan colioform susu pemerahan pagi dan sore di KUD Gemah Ripah Sukabumi, Jawa Barat

\begin{tabular}{lcccc}
\hline Ulangan & \multicolumn{2}{c}{ TPC CFU/mL } & \multicolumn{2}{c}{ Colioform CFU/ml } \\
\hline 1 & Pemerahan Pagi & Pemerahan Sore & Pemerahan Pagi & Pemerahan Sore \\
2 & 880.000 & 850.000 & 11.900 & 10.800 \\
3 & 1.100 .000 & 1.000 .000 & 12.800 & 9.900 \\
4 & 1.500 .000 & 1.400 .000 & 5.800 & 5.200 \\
5 & 1.400 .000 & 1200000 & 8.800 & 6.200 \\
6 & 590.000 & 480.000 & 3.700 & 2.900 \\
7 & 610.000 & 590.000 & 7.600 & 7.400 \\
8 & 1.800 .000 & 1.500 .000 & 6.300 & 6.000 \\
9 & 1.300 .000 & 1.100 .000 & 6.700 & 5.800 \\
10 & 1.500 .000 & 1.400 .000 & 9.200 & 8.800 \\
11 & 1.500 .000 & 1.450 .000 & 4.800 & 4.000 \\
12 & 1.000 .000 & 890.000 & 11.300 & 10.000 \\
13 & 750.000 & 720.000 & 3.500 & 2.900 \\
14 & 700.000 & 690.000 & 500 & 550 \\
\hline Jumlah & 820.000 & 800.000 & 4.900 & 4.700 \\
Rataan & 15.450 .000 & 14.070 .000 & 97.800 & 85.150 \\
\hline
\end{tabular}


besar jika susu diproses oleh peternak sendiri (Nwankwo et al., 2015). Penundaan waktu proses pemerahan dan rendahnya kondisi hygiene menyebabkan pertumbuhan mikroorganisme menjadi cepat (Taufik et al., 2011). Kondisi tersebut juga memudahkan bakteri patogenik untuk tumbuh baik dalam media pemerahan. Hal senada dijelaskan oleh Suwito (2010) bahwa faktor selain kontaminasi susu oleh bakteri kemudian penyimpanan yang buruk, tetapi ada tidaknya infeksi pada bagian putting dalam ambing tersebut. Sapi yang menderita mastitis dapat menyebabkan tingginya 7 jumlah mikroorganisme mencapai 1 x $10 \mathrm{CFU} / \mathrm{mL}$. Lingkungan kandang seperti feses, debu, air, dan peralatan dapat berperan sebagai kontaminan susu (Zurriyati et al., 2011).

Total plate count (TPC) adalah bakteri yang tumbuh per $\mathrm{mL}$ susu selama lebih dari periode waktu yang ditentukan dan rata-rata TPC adalah 100.000 per ml (Kasiram, 2010). Kontaminasi bakteri tersebut berasal dari macam sumber, antara lain penyimpanan susu, kesehatan ambing, sanitasi lingkungan dan alas kandang (LeJeune \& Rajala-Schultz, 2009). Pertumbuhan bakteri dapat ditekan dengan good hygiene dan manajemen peternakan yang baik. Alas kandang harus kering dan seringkali diganti (Gustiani, 2009). Standar good hygiene harus dilakukan selama proses pemerahan, baik dari kebersihan pakaian pemerah maupun ember susu lengkap dengan tutupnya untuk mencegah masuknya debu, kotoran dan rambut di dekat ambing. Penurunan TPC dapat dicegah dengan melukan teat dipping pada bagian putting sapi perah agak dapat mengurangi atau mencegah mikroba masuk dalam susu, hal tersebut terbukti sekitar $70 \%$ bakteri tidak berkembang dalam susu segar (Cahyono et al., 2013). Good hygiene sebelum dan selama proses pemerahan dapat menurunkan kontaminasi bakteri di ambing dan di lingkungan (Estiasih \& Ahmadi, 2009).

Hasil pengujian coliform terhadap sampel air susu sapi segar yang berada dilingkungan KUD Gemah Ripah Sukabumi dengan menggunakan metode most probable number memperoleh hasil bahwa hasil menunjukkan nilai yang mendekati standart SNI (20 MPN/ml). dengan ditemukan kandungan coliform dalam jumlah yang tinggi pada susu segar yang dilakukan pengujian sampel, hal ini membuktikan terdapat cemaran kotoran yang berasal dari hewan ternak pada produk air susu dan sanitasi yang buruk (Murdiati et al., 2004). Menurut Standart Nasional Indonesia (2011) bahwa dengan menerapkan standart operasional prosedur pada proses pemerahan, pengolahan dan penyimpanan produk susu secara tepat akan mencegah timbulnya colioform dalam susu segar.

\section{KESIMPULAN}

Terdapat perbedaan antara kualitas mikrobiologis yaitu TPC dan colioform antara susu pada pemerahan pagi dan sore serta dalam kategori normal sesuai standar SNI 3141.1-2011.

\section{DAFTAR PUSTAKA}

[BSN] Badan Standarisasi Nasional. 2011. SNI 3141.1:2011 Tentang Syarat Mutu Susu Segar. Badan Standarisasi Nasional. Jakarta.

Cahyono, D., M.C. Padaga, \& M.E. Sawitri. 2013. Kajian kualitas mikrobiologis (total plate count (TPC), enterobacteriaceae, dan Staphylococcus aureus) susu sapi segar di Kecamatan Krucil Kabupaten Probolinggo. Jurnal Ilmu dan Tehnologi Hasil Ternak 8(1)1-8.

Gustiani, E. 2009. Pengendalian cemaran mikroba pada bahan pangan asal ternak (daging dan susu) mulai dari peternakan sampai dihidangkan. Jurnal Litbang Pertanian 28(3):96-100.

Estiasih, T. \& K.G.S. Ahmadi. 2009. Teknologi Pengolahan Pangan. Rajawali Press. Jakarta.

Hidayat, A. 2010. Manajemen Kesehatan Pemerahan. Dinas Peternakan Jawa Barat. Bandung

LeJeune, J.T. \& P.J. Rajala-Schultz. 2009. Unpasteurized Milk: A Continued Public Health Threat. Food Safety. Clinical Infectious Diseases 48(1):93-100.

Meutia, N., T. Rizalsyah, S. Ridha, \& M.K. Sari. 2016. Residu antibotika dalam air susu segar yang berasal dari peternakan di wilayah Aceh Besar. Jurnal Ilmu Ternak 16(1):1-5.

Kasiram, M. 2010. Metode Penelitian KualitatifKuantitatif. Universitas Islam Negeri Maliki Press. Malang.

Murdiati, T.B., A. Priadi., S. Rachmawati, \& Yuningsih. 2004. Susu pasteurisasi dan penerapan HACCP (Hazard Analysis 
Critical Control Point). Jurnal IImu Ternak dan Veteriner 9(3):172 180.

Nwankwo, I.U., N. Amaechi, \& W.A. Adiele. 2015. Microbial evaluation of raw milk from dairy farms in Udi L.G.A Enugu State, Nigeria. Journal of Agriculture and Veterinary Science. 8(3):60-65.

Putri, A. M, \& Kurnia, P. 2018. Identifikasi keberadaan bakteri coliform dan total mikroba dalam es dung-dung di sekitar kampus Universitas Muhamadiyah Surakarta. Media Gizi Indonesia 13 (1):41-48.

Suwito, W. 2010. Bakteri yang sering mencemari susu: deteksi, patogenisis, epidemiologi, dan penegndalian. Jurnal Litbang Pertanian 29(3):96-100.

Taufik, E., G. Hildebrandt, J.N. Kleer, T.I. Wirjantoro, K. Kreausukon, K.H. Zessin,
M.P.O. Baumann, \& F.H. Pasaribu. 2011. Microbiological quality of raw goat milk in Bogor, Indonesia. Media Peternakan 43:105-110.

Zain, W.N.H. 2013. Kualitas Susu Kambing Segar Di Peternakan Umban Sari Dan Alam Raya Kota Pekanbaru. Jurnal Peternakan 10(1):24-30.

Zurriyati Y., R.R. Noor, \& R.R.A. Maheswari. 2011. Analisis molekuler genotipe kappa kasein ( $\kappa$-kasein) dan komposisi susu kambing Peranakan Etawah, Saanen dan Persilangannya. Jurnal Ilmu Ternak dan Veteriner 16(1):61-70. 